\title{
An Exploratory Study On Human Capital Investments
}

\author{
Dumani Markjackson ${ }^{1}$, Alhassan Odiniya Innocent ${ }^{2}$ \\ ${ }^{1}$ Department of Banking and Finance, Federal Polytechnic, Ekowe, PMB 110, Yenagoa, Bayelsa State, Nigeria. \\ ${ }^{2}$ Department of Accounting, Federal Polytechnic, Ekowe, PMB 110, Yenagoa, Bayelsa State, Nigeria. \\ DOI: 10.29322/IJSRP.10.06.2020.p10277 \\ http://dx.doi.org/10.29322/IJSRP.10.06.2020.p10277
}

\begin{abstract}
Human capital is a valuable resource; it pulls the other factors of production and gives strategic foresight to every corporation and nation. It plays an integral part in the value creation process of modern corporations and economies. Thus, several studies have been carried out to ascertain the link between investments on human resource on the performance of the micro and macro economy. This paper sets to explore available literature and synthesize the ideas and positions there-in to take an informed position on the categorization of human capital investments. To achieve this, the study adopted a desk research approach and reviewed several related conceptual postulations, theories and empirical studies on the subject to lay credence to take an informed position. The findings revealed that there is a huge link between economic theory and empirical findings on the vital role human capital investments play in enhancing corporate growth and employee earnings. The major area of deviation is on the valuation of the returns on investment on resource; which is still evolving. Specifically, the study found a proportionate link between investments on training, education, staffing, health, etc. on the performance of corporations and the benefits it tilt to the economy. On this premise, the study concludes that human capital is an investment and therefore should be categorized as a type of investment that is an invaluable component in the production process of a corporation and nation.
\end{abstract}

\section{INTRODUCTION}

$\mathrm{T}$ The evolution of the phrase 'human asset' can be traced to the work of Adam Smith in quite a few centuries ago, who posited that what constitute capital is not just fixed assets, and that capital also comprises core human abilities (Schultz, 1961; Goldin, 2014). This was further put succulently by Arthur Pigou in 1928 when he said "there is such a thing as investment in human capital as well as investment in material capital (Bruce-lockhart, 2016). The concept, however, was robustly developed in economic lexicon by Shultz (1961), Becker (1964), and Mincer (1958) (Edgard, 2010; Cesyniene \& Stankeviciene, 2011; Jacobs, 2006). These scholars both alluded to the important role human asset investments play in enhancing the productive capacity of an economy (Edgard, 2010). Irrespective of this, the central theme of books, lectures and scholarly dissertations on the classification of investments has been dominated by outlays in physical and financial assets. Similarly, this was the case in the agrarian and industrial eras of civilization where the productive process was believed to be stimulated by land, financial capital and the strength of men (Tadic, Barac \& Plazonic, 2015). However, in this present-day information economy which is driven by innovation - invention and intellectual architecture and given the role human asset plays in enhancing growth both in the firm and the economy; this area of research has now attracted several scholarly essays (Edgard, 2010; Odhon'g \& Omole, 2015). This is understandably due to the shift in focus from tangible assets in the production process to more intangible elements like the multifaceted skill sets of the employee - his experiences, talents, expert knowledge, and artistic abilities (Bessong, Effiok \& Usang, 2012). Unlike other resources of a corporation, human capital is not easily copy-able and thus, this distinctive skill sets help shape and give competitive edge over corporations that fails to commit funds to the training and retraining and health of her human asset. (Becker and Gerhart, 1996, and Barney, 1991) attributed the difficulty in imitation of human capital as causal ambiguity and value building policies put together overtime that could not be bought easily in the labour market (Stiles \& Kulvisaechana).

No doubt, the foundation of a robust and sustainable competitive growth is a function of human capital (Tadic el at, 2015; Besong et al, 2012; Mayo, 2001). In a survey aimed at determining the growth factor of a firm, human resource only ranked second to access to market in the growth of a corporation (Endeavor, 2014). This implies that human resources to a large extent runs our businesses and develop company strategy to remain relevant in the marketplace. This has made corporations to move towards "employee first policy from customer first". This is because corporations have come to know that pleased employees make customers even happier.

The productive capacity of a worker is highly correlated to his health, work experience, skills, qualifications and education. Thus making it imperative for employers to invest in their training and retraining just like they similarly invest in fixed and current assets to consolidate on their productive capacity (Schultz, 1961; Riley, Michael \& Mahoney, 2016). Although human capital investments are regarded as asset but unlike other assets that are valued and reported on the statement of financial position, human capital is not captured as an asset in the statement of financial position but rather it is treated as an expense in the profit and loss account of a firm (Sunday, 2014). This is indicative that although human capital is an asset it is still considered as an expense to a firm in the books of account. Thus, a major area of deviation is valuation and reporting of human asset. There is no acceptable way of valuing returns on human asset investments by scholars unlike fixed and current assets of a corporation. Consequently, a major area of challenge about human asset accounting is the valuation and reporting of returns on human assets.

\subsection{Objective of the study}


The study set out to explore available literature and synthesize the ideas and positions there-in to take an informed position on the discourse of human capital investment. To achieve this, the study adopted a desk research approach and reviewed several related conceptual postulations, theories and empirical studies on the subject to lay credence to take an informed position.

\subsection{Significance of the study}

Theoretical and empirical studies on human asset investment are unquestionably regarded as a significant aspect in academic discourse. This study stand to take an informed position that would serve as a compendium of knowledge on the categorization of human asset investments. By so doing, the paper would also reveal if human capital investments enhance the performance of corporations and the macro economy to the reading public, researchers and the academia.

Additionally, despite the number of studies carried out on this topic since 1960, there is still no consensus amongst researchers and this topic is still as confounding as it was in the beginning. This study is just another attempt to add to this growing body of knowledge for researchers, academics and managers to make reference to.

\subsection{Conceptual Framework}

Human capital is the core and innate abilities of an individual used in the productive process of an organisation or national economy. This implies that the productive process is not only driven by fixed capital but also by the "acquired and useful abilities of all the inhabitants or members of the society" as posited by Adam Smith.

Consequently, human capital is the intangible attributes of an employee - which could be innate or assimilated via on the job training or education. Human capital is therefore seen as the combination of intellect, skills, experiences, talent and the artistic ability of an employee directed at adding value to productive process that will be beneficial to both the firm and the macro economy (Bruce-Lockhart, 2016; Schultz, 1961; Becker, 1964; Abdullah \& Othman, 2016). Thus, human capital has variously been regarded as the most valuable asset of a corporation due to its ability to shape strategy and add value to the productive process of the micro and macro units of the economy. A productive and creative labour force contribute to the long term sustained growth of a nation and firm (Bruce-Lockhart, 2016).

This has made scholars to strongly posit that funds should be committed to human capital development just like funds are allocated for the maintenance and replacement of plants and machineries to enhance production. The major challenge in doing this is that, unlike fixed assets and current assets that are captured in the statement of financial position of a firm, the value for human assets are not captured. It is only considered and record as an expense in the production process in the trading, profit and loss account.

The criteria for valuing people as asset are cost based, market based and economic based. Firstly, the cost based approach looks at acquisition or replacement cost. The costs of recruiting an employee can be assessed and then depreciated over the expected future service of the person hired. Alternatively the person's gross remuneration can be used as a base. Secondly, the market base criteria look at the price to be paid in an open market as the reflection of the value of a person. Value is very difficult to assess, however, and does not take account of the value of service continuity in itself. Thirdly, the economic based approach looks at cash inflows expected by the firms in relation to the contribution of the human asset, calculated as the present value of the expected net cash flows. Simply put, excess of earnings over outlays. This is good for individuals whose efforts are directly related to identifiable income.

\subsection{Theoretical Framework}

The theoretical foundation of this study is hinged on the human capital theory. Human capital theory was moulded by the Shultz (1961), Becker (1964), and Mincer (1958) (Edgard, 2010; Jacobs, 2006). The central theme of the human capital theory is hinged on investment in the health, formal or informal education, training and retraining of an employee in anticipation of the returns on investment (Kucharcikova, 2014). Education, training and retraining is the pivot through which an employee's capabilities are developed (Fugar, Ashiboe-Mensah \& Adinyira, 2013) and these are regarded as the most important investment in human capital (Becker, 1992). The theory ties ones expected returns on human capital as a function of the volume of outlay committed to attending training, retraining, workshops and seminars in order to sharpen one's skills and remain relevant. Training, workshop and seminar fees are cost intensive and as such only people that still have the tendency to recoup more than their investments would commit their scarce resources to human capital development. Thus, those who have limited time in the labour force would ordinary opt not to commit their scarce resources for such an endeavour. (This could also stand true for corporations).

The theory holds that training can be regarded as investment in human asset because it could enhance output, quality and workplace relationships. This added value to the corporation is not organic, thus organisations must strive to motivate and encourage them and even put in place retention mechanisms (like stock options, bonuses and training contracts - bond) to ensure that they remain with the firm in order to recoup the direct and indirect costs incurred.

The theory further posits that the accumulation of skills, experiences, and knowledge acquired via trainings adds value to corporations hence the production process; thus capital comprises of the core capabilities of the staff of a corporation or nation (Schultz, 1961; Becker, 1964). The consolidation of the productive capacity of a firm is an embodiment of all the outlays and human resource management techniques like motivation and monitoring of its personnel to get the best out of them (Flamholtz \& Lacey, 1981).

Swanson (2001) summarized these positions and presented vital links in human capital theory, resources, education and training, output, and earnings. He posited that there is a link between learning and quality service and output. The cornerstone to this position is that increase in training lead to increase in production and that this in turn lead to increase in earnings to both the individual and the firm. This model is presented below; 


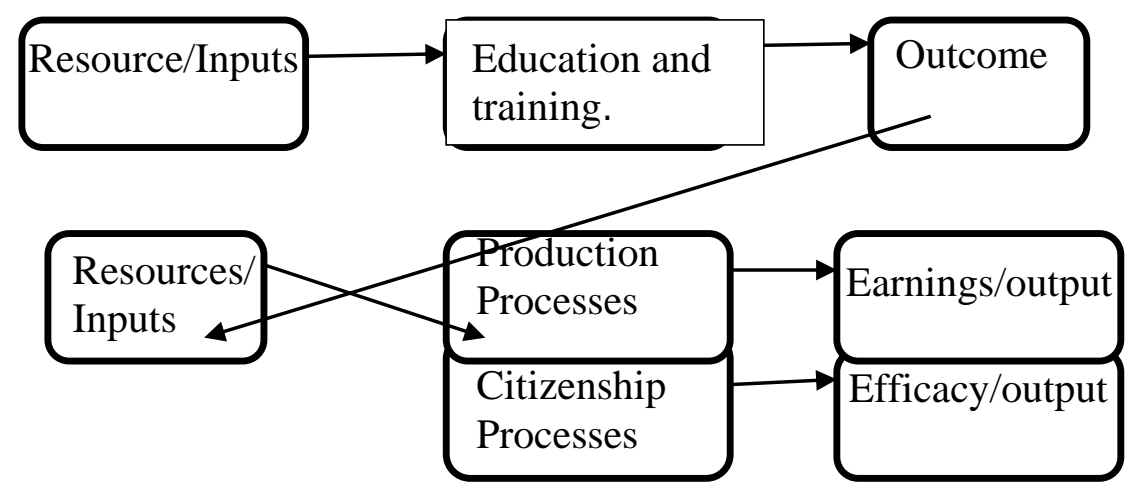

Source: Adopted from Swanson, 2001: 110)

\subsection{Review of Empirical Studies}

Several empirical studies have been carried out to ascertain the impact of investment in human capital and the returns on investments to the individual, the firm and the economy. This is irrespective of the subject not having a clearly agreed metric, suitable data and method of evaluation. Yet scholars have studied various components that make up human capital investments and value creation in firms.

To ascertain the role of human capital investment on business returns of firm listed in the Zagreb Stock Exchange, Croatia in 2012, Tadic et al (2015); understudied 128 medium and large companies in the exchange. Secondary data was obtained from the Croatian Financial Services Supervisory Agency. Human capital investment was measured by annual salary divided by number of employee while business excellence was measured by the BEX indix, which augments the profitability, value added, liquidity and financial strength. The analyses concluded that extra salaries and bonuses enhance corporate performance. This informs the need for human capital investments, securing the retention and further personnel development to maintain market position and secure its continuous growth.

(Odhon'g \& Omolo, 2015), examined the impact of human capital investment on the performance of pharmaceutical companies in Kenya. They specifically sought to ascertain the impact of training, education, knowledge management and skills development (which are all measures for investment in human capital) on firm performance. Qualitative data was obtained via questionnaires. The simple random technique was used to arrive at a sample size of 200. Descriptive and inferential statistics was employed for the analysis. The analyses indicated that training, education, knowledge management and skills development have a significant relationship with the performance of the firms considered in the study.

The study by the duo of Poteliene and Tamasauskiene (2013) was carried out specifically to measure the human capital investment returns or payback on education in Lithuania from 2004 to 2011. To achieve this, the authors adopted the cost benefit approach to determine the net product value of investments in education. The model captured the earnings of more educated workers to lower education and the retirement age and a discount rate. The results indicate that investment in higher education yields more returns in Lithuania.

Ahesha and Thrikawala (2012) set out to ascertain the impact of human capital investment on the return performance of 40 select companies in Sri Lanka for 2009 and 2010. The specific objective of the study was to ascertain the impact of investments on training and human capital development on the returns on asset, equity and market capitalisation of the firms. The findings from the analysis show that human capital investments play a significant role in enhancing the financial performances of these firms in the Colombo stock exchange.

The study by Al-Ghazawi (2012) examined the impact of human asset investment on effectiveness in commercial banks in Jordan. Specifically, the study set out to ascertain the impact of investments on staffing, training and development, incentives, and retention policy on the dependent variables: human capital value added (HCVA), human capital return on investment (HCROI), and turnover rate of the banks in Jordan. Data for the study was obtained from secondary sources and via questionnaires. The analytical adopted was the ordinary least square technique. Empirical results show that there is a direct significant impact from both training and development and employee incentives system on the human capital return on investment and human capital value added. The study also revealed that there is a direct impact from retention policies on the turnover rate.

Similary, the paper by Olowolaju and Oluwasesin (2016) investigated the effect of investments in human capital on the profitability of 10 select manufacturing companies in Nigeria. The objective of the study was to ascertain if salaries and wages, training, contributory pension and health have a significant impact on profit before tax (or not). To achieve this, the authors obtained secondary data for 10 years period (from 2005 to 2014). The analysis was done using panel regression and descriptive statistics. The results show that there is a linear relationship between expenditure on human capital and profitability. More specifically, the results revealed that outlay on health had a more significant impact on the profit before tax of the select firms than salaries and wages, training and contributory pension.

In another study by Bessong et al (2012), the researcher examined the relationship between human asset investments of 10 select banks in the Nigerian Stock Exchange. The paper used the cost based, market based and economic based criteria in evaluating human capital investments of deposit money banks on the performance. Secondary information was obtained via survey of existing documents. Data for the analysis was primarily obtained via questionnaires and the data was analysed using the ordinary least squares. The results revealed that human capital investments and bank performance is statistically significant.

Masuluke and Ngwakwe (2018) paper studied the impact of investments in human capital on the net profit of 28 select 
companies in the FTSE/JSE. Secondary data was obtained from the survey of the integrated reports of the companies. The variables obtained were net profit, human capital investments and sales turnover (the control variable). The numeric values were analysed using regression technique. The findings revealed that there is significant relationship between the study parameters. It also emerged that human asset investment has a negative relationship with net profits in the short run, but in the long run, the relationship is linear and significant.

Ifurueze, Binglar and Etale (2013) assessed the impact of human asset investments on goodwill of 10 select banks in the Nigeria Stock Exchange. The measures of human capital investments adopted in the study are asset turnover, invested capital turnover and return on asset; while the measures of goodwill are return on investment, return on equity and earnings per share. Secondary data was obtained from 2007 to 2011 from the annual financial reports of the sampled firms of the study. The empirical analysis indicates that there is a direct and significant relationship between investments in human resource and goodwill of banks in Nigeria. It also emerged that human asset capitalization in the statement of financial position would be a stimulant to stakeholders making more informed decision.

This review of related empirical studies is not by anyway exhaustive but this has given the researcher an idea of the outline and the nature of human capital investments, in order to make an informed decision whether to categorise human asset as an investment (or not).

\section{DISCUSSION}

The findings are proportionately similar. There is a huge link between economic theory and empirical findings on the vital role human capital investments play in enhancing corporate growth and employee earnings. The major area of deviation is on the valuation of the returns on investment on human resource; which is still evolving. Irrespective of this, scholars have used various primary metrics to ascertain the link between investments on training, education, staffing, health, etc. on the performances of corporations and the benefits it tilt to the economy. The findings have variously reported this link as linear and significant. More specifically, the study indicate that human asset investments are of significant value first, to the individual; second, to the corporation; and third, to the macro economy. This implies that investments in human capital directly enhance the productive capacity of a firm, and indirectly to the economy at large. The reviews show that there is a strong correlation between education and training on corporate performance. Further to this is that, as the productive output of a corporation increase, as a result of the human capital mix knowledge, skills, artistic ingenuity, and experiences of the worker - so does his remuneration and other pecuniary benefits. Unambiguously, the analyses indicate that investments in training, retraining, education, health, staff (or recruitment) and staff benefits are significant growth factors in corporations. The study is aware that this added value to the corporation is not biological, thus organisations must endeavour to motivate, encourage and even put in place retention mechanisms (like stock options, bonuses and training contracts - bond) to ensure that they remain with the firm in order to payback even more than the direct and indirect costs incurred in the training period. This makes the labour fluidity argument (specifically, labour mobility) adduced as the reason to limit investments on human resource as an implausible postulation.

The study is aware of the concerns raised especially on how to value the returns on human capital investments like other types of asset class and its current treatment as an expense item in the books of account. The reason for this may not be farfetched as some scholars sees human capital as an expense that needs to be minimised. Thus, they see the human capital (experiences, skills, artistic ingenuity) in the creation circle as a causal element rather than an explicit value creator (Ulrich, 1998). Human resource should be nurtured and groomed to bloom and be the centre piece of a firm's competitive strategy and advantage. Examples abound of how human ingenuity has transformed the fortunes of corporations and even created something out of virtually nothing. Obviously, the marginal productivity of people who are sick (or of poor health), lacks technical abilities, skills, and experience will offer far less than someone who has abundant health, skills and cognate experience.

\section{CONCLUSION}

Human capital is a valuable resource; it pulls the other factors of production and gives strategic foresight to every corporation and nation. According to (Schultz, 1961, p. 16), "the man without skills and knowledge is leaning terrifically against nothing." Simply put corporations and nations who fail to groom the skills and knowledge of her employees and citizens that is expecting competitive edge and sustainable growth is leaning terrifically at nothing.

Although, the valuation and recording of the returns on human capital investments are problematic and still evolving, the returns on human capital investments would transcend the valuation of assets on the statement of financial position and other books of account, as it may be almost impossible to capture the intrinsic value of a person and the human assets of a corporation. Thus, it should be nurtured, developed and retained in order to enhance the market share of the firm.

The paper concludes that human capital is an investment and therefore should be categorized as a type of investment that is an invaluable component in the production process of a corporation and nation.

\section{REFERENCES}

[1] Abdullah, N. N. \& Othman, M. (2016). The contribution of human capital investment in the growth of East Asian economy - A literature review. Journal of Economics and Business Research, 1, 190-203.

[2] Ahesha, P. \& Thrikawala, S. (2012). Impact of human capital investment on firm financial performances: An empirical study of companies in Sri Lanka, 54(3), 11 - 16. doi: 10.7763/IPEDR

[3] Al-Ghazawi, M. (2012). The impact of investments in human resources activities on the effectiveness of investment in human capital: The case of commercial banks in Jordan. International Journal of Business and Social Science, 3(18), $253-261$.

[4] Becker, G. (1962). Investment in human capital: A theoretical analysis. Journal of Political Economy, 70, 9- 49

[5] Becker, G. (1964). Human capital. Columbia University Press. New York.

[6] Bessong, P. K., Effiok, S. O., \& Usang, O. U. E. (2016). Human resource valuation and the performance of selected banks in Nigeria. Global Journal of Social Sciences, 11(2), $133 \quad-\quad 140 . \quad 10$ Doi: http://dx.org/10.4314/gjss.v11i2.5. 
[7] Bruce-Lokart, A. (2016). Why do we call it human capital. World Economic Forum. Retrieved on 23rd June, 2019.

[8] Cesyniene, R. \& Stankevičiene, A. (2011). The role of human capital in value creation: theoretical insights. Ekonomika, 90(4), 49-62.

[9] Edgard, B. C. (2010). Investing in human capital: Integrating Intellectual capital architecture utility theory. The Journal of Human Resource and Adult Learning, 6(1), 29 - 40.

[10] Endeavor, I. (2014). The three most important resources companies need to succeed. Entrepreneurship Ecosystem Insights. Retrieved on: 23rd June, 2019.

[11] Flamhotz, E. G. \& Laccey, J. M. (1981). Personnel management, human capital theory and human resource accounting. Los Angeles: Los Angeles University Press.

[12] Fugar, F. D. K., Ashiboe-Mensah, N. A., \& Adinyira, E. (2013). Human capital theory: implications for the Ghanaian construction industry development. Journal of Construction Project Management and Innovation, 3 (1), $464-479$.

[13] Goldin, C. (2014). Human Capital. Handbook of Cliometrics, Claude Diebolt and Michael Haupert, Springer-Verlag.

[14] Ifurueze, S. M., Binglar, P., \& Etyale, L. (2013). An assessment of human resource capital and goodwill: a study of selected commercial banks in Nigeria. Journal of Business \& $\quad$ Management Volume 2(4), 36-48.

[15] Jacobs, B. (2006). Real options and human capital investment, $1-23$.

[16] Kucharcikova, A. (2014). Investment in the human capital as the source of economic growth. Periodica Polytechnica, 22(1), 29-35. doi:10.3311/PPso.7426

[17] Masuluke, M. F. \& Ngwakwe, C. C. (2018). Relationship between human capital investments and firm's net profit. Journal of Accounting and Management, 8(1), 37 - 46

[18] Mayo, A. (2001). Human value of the enterprise. London: Nicolas Brearley Publishing.

[19] Odhon'g, E. A. \& Omole, J. (2015). Effect of human capital investment on organizational performance of pharmaceutical companies in Kenya. Global Journal of Human Resource Management, 3(6), 1 - 29.
[20] Olowolaju, P. S. \& Oluwasesin, O. D. (2016). Effect of human capital expenditure on the profitability of quoted manufacturing companies in Nigeria. Asian Journal of Finance \& Accounting, 8(2), 155 - 170. doi:10.5296/ajfa.v8i2.10197

[21] Poteliene, S. \& Tamasauskiene, Z. (2013). Human capital investment: Measuring returns to education. Social Research, 4(33), 56-65.

[22] Riley, S. M., Micheal, S. C., \& Mahoney, J. T. (2016). Human capital matters: Market valuation of firm investments in training and the role of complementary assets. Strategic Management Journal, 38, 1895 - 1914. Doi: $10.1002 / \mathrm{smj} .2631$.

[23] Schultz, T. W. (1961). Investment human capital. The American Economic Review, 51(1), $1-17$.

[24] Stiles, P \& Kulvisaechana, C. (n.d). Human capital and performance: A literature review. The Judge Institute of Management, University of Cambridge. Page $1-42$.

[25] Sunday, K. J. (2014). Human capital accounting: the dichotomy of value representation. Review of Public Administration and Management, 3(5), 45 -52. Available on: www.arabianjbmr.com/RPAM_index.php

[26] Tadic, I., Barac, Z. A., \& Plazonic, N. (2015). Relations between human capital investments and business excellence in Croatian companies. International Journal of Mechanical and Industrial Engineering, 9(3), 850 -855 .

\section{AUTHORS}

First Author - Dumani Markjackson, Department of Banking and Finance, Federal Polytechnic, Ekowe, PMB 110, Yenagoa, Bayelsa State, Nigeria.

Second Author - Alhassan Odiniya Innocent, Department of Accounting, Federal Polytechnic, Ekowe, PMB 110, Yenagoa, Bayelsa State, Nigeria. 